\section{URS MONARCA - a new hexaploid oat cultivar with excellent grain yield and wide adaptation}

\section{Marcelo Teixeira Pacheco ${ }^{1}$ and Luiz Carlos Federizzi ${ }^{1^{*}}$}

\begin{abstract}
The Oat Breeding Program of the Federal University of Rio Grande do Sul (UFRGS) release in 2019 a new cultivar URS MONARCA developed from the single cross UFRGS 06 6083-3 / UFRGS 00 6183-2. URS MONARCA presents high grain yield, high grain quality, wide adaptation, short plant height and excellent milling yield.
\end{abstract}

Keywords: Avena sativa, milling yield, plant height and test weight.

\section{INTRODUCTION}

Oat belongs to the Poaceae botanical family, Poideae subfamily, Aveneae tribe, and Avena genus. The various oat species form a polyploid series, represented by diploid, tetraploid, and hexaploid species, with seven basic chromosomes. The cultivated oat (Avena sativa $\mathrm{L}$.) is an allohexaploid species consisting of six sets of basic chromosomes $(2 n=6 x=42)$, formed from the aggregation of three subgenomes (AA, CC, and DD) from ancestral diploid species (Rajhathy and Thomas 1974). Oats is an important crop used for food, feed, and forage worldwide. In subtropical environments, such as in Southern Brazil, oat is an important component of grain production during the winter/spring seasons in no-tillage crop system rotations, usually with soybeans grown in the summer as the more important crop (Locatelli et al. 2007). Selection for earliness and short plant height is desired by various oat breeding programs. Heading at the right time, under favorable environmental conditions, is essential to achieve high grain yields, and the number of heads per area, as well as the number of florets and grains per head are key yield components. Reduced plant height may help to decrease crop losses attributable to lodging (Zimmer et al 2018). In Brazil, especially in the southern region, white oat cultivation has been gaining increasing prominence, especially in the last two decades, having reached 375 thousand ha of cultivated area in 2018, with production of about 800 thousand tons. Corresponding to about 300 thousand tons more than the previous historical record, reached in 2005, according to official data from CONAB (2019). This success is due, among reasons, to the availability to farmers of cultivars with high agronomic performance and specific cultivation technologies. This has been possible, in large part, due to the joint efforts of various research institutions under the coordination of the Brazilian Oat Research Commission (CBPA), who work for oat culture, developing and disseminating relevant research. In particular, among the activities coordinated by CBPA, are cooperative assays to evaluate grain yield and other agronomic traits of new white oat lines that are developed by breeding programs.
Crop Breeding and Applied Biotechnology 20(2): e306220213, 2020 Brazilian Society of Plant Breeding. Printed in Brazil http://dx.doi.org/10.1590/198470332020v20n2c29

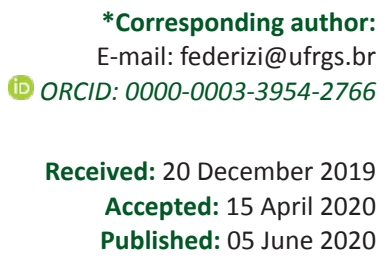

${ }^{1}$ Universidade Federal do Rio Grande do Sul, 91.540-000, Porto Alegre, RS, Brazil 
Most successful crop breeders are scientists who also become "engineers" of a cultivar delivery pipeline, translating basic knowledge directed toward release of newly improved cultivars that are rapidly taken up by farmers (Reynolds et al. 2019).

The objective of this work is to present how the new cultivar was obtained (the breeding method) and the agronomic performance of URS MONARCA in different environment of South Brazil.

\section{PEDIGREE AND BREEDING METHOD}

In the Oat Breeding Program at UFRGS we use a pedigree modified as breeding method. The main characteristics and modifications of the breeding method were described by Nava et al. (2016). URS MONARCA is a hulled F6-derived line developed from the simple cross UFRGS 06 6083-3 / UFRGS 00 6183-2. The cross between UFRGS 06 6083-3 / UFRGS 00 6183-2 was carried out in 2008 and the genealogy of the parent UFRGS 06 6083-3 is 'UFRGS 99 5088-3 / UFRGS 00 6049', and the genealogy of the parent UFRGS $006183-2$ is 'Pc 68*5 / Starter // UFRGS 8'.

The first filial generation (F1) was sown in the field at Agronomical Experimental Station (EEA/UFRGS) in the growing season of 2009. Panicles from all F1 plants were harvested and bulk-threshed, giving rise to seeds of the second filial generation (F2). The segregating population developed from the cross UFRGS 06 6083-3 / UFRGS $006183-2$ was advanced and selected from F2 to F6 using a modified pedigree method (Nava et al. 2016). All segregating populations were grown in the field in a non-till system during the normal season for the oat crop (planted in June and harvested in October). At each segregating generation, only panicles were selected in the field and after were threshed individually and the grains screened in the laboratory for size, grain filling, uniformity and absence of diseases (black spots, fusarium ).

During the growing season of 2014, three F5:6 lines were sown under the identification numbers 146155-1 to 146155-3. The line number 3, presented high phenotypic uniformity and it was harvested in bulk, threshed, and coded as 'UFRGS 146155-3'.

The new line was first tested in a preliminary trial (2015) and then evaluated over three consecutive years in a series of cooperative trials, including the Regional Trial (ERLA 2016), the Brazilian Trial of first (EBLA 2017) and second year (EBLA 2018). In the cooperative trials, the line 'UFRGS 146155-3' was tested in 26 experiments, carried out in eight to ten locations each year, distributed in the states of Paraná, Rio Grande do Sul, and Santa Catarina. No insecticide or fungicide was applied in any experiments. In all trials, UFRGS 146155-3 was compared with three check cultivars. For statistical analysis, we utilized the T-test for paired observations (Steel \& Torrie,1980) comparing the mean of the line UFRGS 146155-3 with the best checks that were present in all locations and years (URS 21). The results obtained in the preliminary trial and in the three years of cooperative tests, the line UFRGS 146155-3 showed excellent agronomic performance (data presented below) and it was released as a new cultivar, 'URS MONARCA'.

\section{AGRONOMIC PERFORMANCE}

The line UFRGS 146155-3 was first evaluated in a Preliminary trial at EEA/UFRGS in 2015. UFRGS 146155-3 was compared with checks cultivars URS 21, Barbarasul, and URS Corona for the traits : number of days from emergence to heading, plant height, lodging, grain yield and test weight. URS Corona had the highest mean grain yield of $2259 \mathrm{~kg}$ $\mathrm{ha}^{-1}$ and UFRGS $146155-3$ had a mean grain yield of $2831 \mathrm{~kg} \mathrm{ha}^{-1}$, or $125.3 \%$ of the best check. For test weight, UFRGS

Table 1. Locations and years that the Regional Trial of Oat Lines (2016) and Brazilian Trial of Oat Lines of first (2017) e second year (2018) were grown

\begin{tabular}{lcccccccccccc}
\hline & \multicolumn{10}{c}{ Locations $^{\S}$} & \multicolumn{1}{c}{ Nr. of } \\
\hline Year & CL & ELD & AP & PF & TM & CN & PG & GUA & STO & LON & MS & Locations \\
2016 & $\mathrm{x}$ & $\mathrm{x}$ & $\mathrm{x}$ & $\mathrm{x}$ & - & - & $\mathrm{x}$ & $\mathrm{x}$ & - & $\mathrm{x}$ & $\mathrm{x}$ & 8 \\
2017 & $\mathrm{x}$ & $\mathrm{x}$ & $\mathrm{x}$ & $\mathrm{x}$ & $\mathrm{x}$ & $\mathrm{x}$ & $\mathrm{x}$ & $\mathrm{x}$ & $\mathrm{x}$ & $\mathrm{x}$ & $\mathrm{x}$ & $9+10$ \\
\hline 2018 & $\mathrm{x}$ & - & - & $\mathrm{x}$ & $\mathrm{x}$ & $\mathrm{x}$ & $\mathrm{x}$ & - & $\mathrm{x}$ & $\mathrm{x}$ & $\mathrm{x}$ & 8 \\
\hline
\end{tabular}

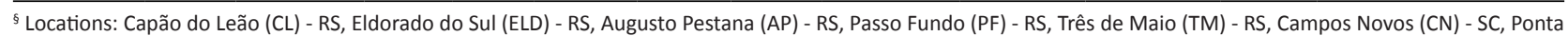
Grossa (PG) - PR, Guarapuava (GUA) - PR, Santa Tereza do Oeste (STO) - PR, Londrina (LON) - PR and Mauá da Serra (MS) - PR. 
146155-3 had weight of $53.3 \mathrm{~kg} \mathrm{hL}^{-1}$, which was higher than $39.6 \mathrm{~kg} \mathrm{hL}^{-1}$ presented by the best check for the trait URS 21. The line UFRGS $146155-3$ was eight days earlier (70 days from the emergence to heading), than the check cultivars and it was shorter, mean of $107 \mathrm{~cm}$, compared with 122, 112, and $118 \mathrm{~cm}$ observed for the check cultivars URS 21,

Table 2. Grain yield, test weight, thousand kernel weight, plant height, and lodging of the oat line UFRGS $146155-3$ and the check cultivars evaluated in the Regional Trial of Oat Lines (2016), National Trial of Oat Lines of first-year (2017), and National Trial of Oat Lines of second-year (2018)

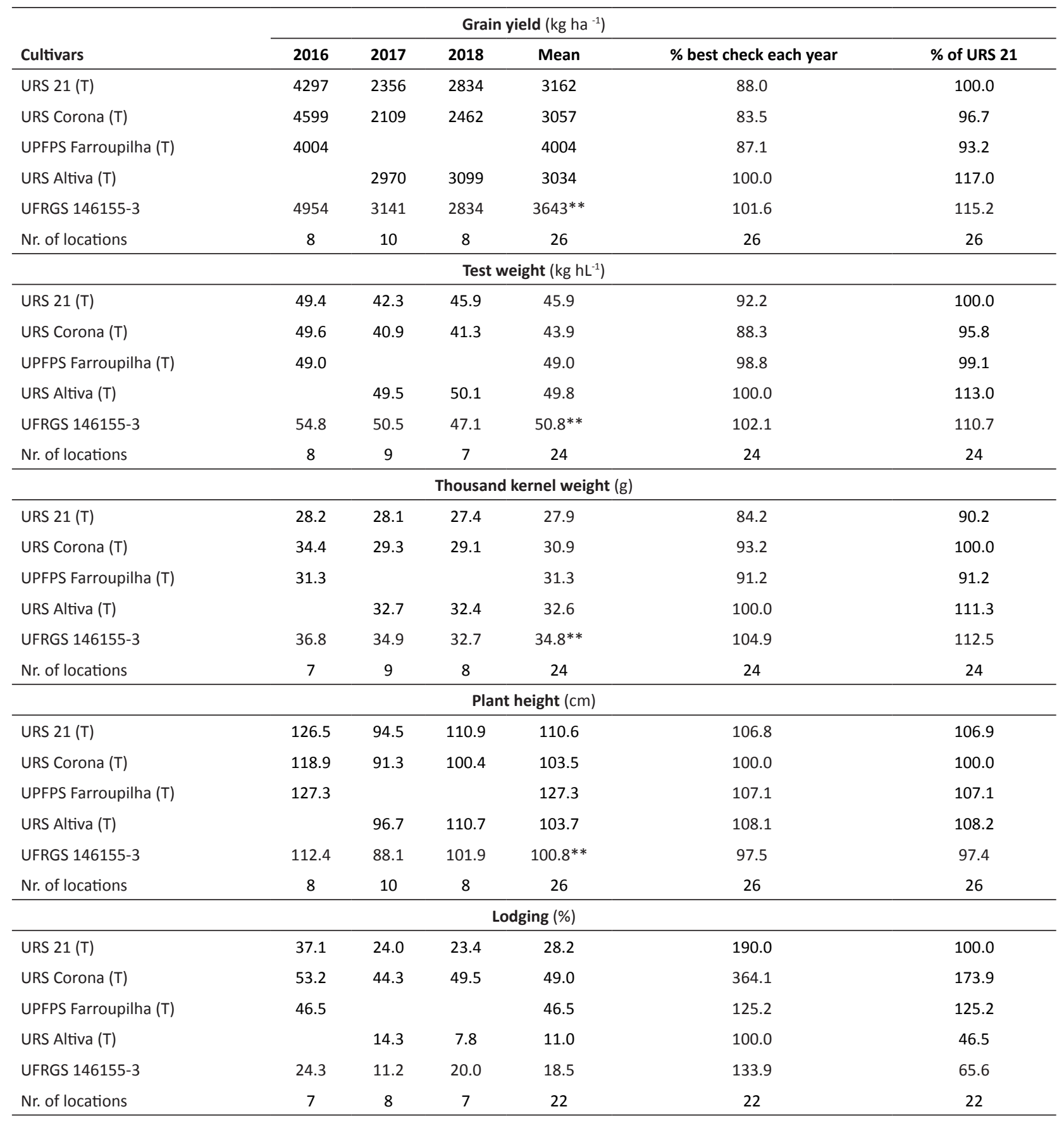

** Mean significative different from that of URS 21 by the $\mathrm{t}$ test of paired comparison $(\mathrm{P}<0.01)$ 
Barbarasul, and URS Corona, respectively (data not shown).

During the cooperative tests, the oat line UFRGS 146155-3 was evaluated for three years in eight to ten locations across the states of Rio Grande do Sul (Augusto Pestana, Capão do Leão, Eldorado do Sul, Passo Fundo and Tres de Maio), Paraná (Guarapuava, Londrina, Mauá da Serra, Ponta Grossa and Santa Tereza do Oeste), and Santa Catarina (Campos Novos) (Table 1). These trials were carried out under the coordination of the Brazilian Oat Research Committee (CBPA). Table 2 shows the results for grain yield, test weight, thousand kernel weight, plant height, and lodging obtained for the line UFRGS 146155-3 and the check cultivars, evaluated in the Regional Trials of Oat Lines (ERLA) and Brazilian Trials of Oat Lines (EBLA). During the three years of cooperative testing, the performance of oats was very different, as expected for a sub-tropical environment. In 2016, the grain yield and parameters of quality were substantially better than those of 2017 and 2018 (Table 2). In 2016, the line UFRGS 146155-3 was tested in eight environments, and it had mean grain yield of $4954 \mathrm{~kg} \mathrm{ha}^{-1}$, showing all the potential of the line for producing grain of excellent quality in the environments of South Brazil. Over the three years and 26 locations, the mean grain yield of the best check (URS 21) was $3162 \mathrm{~kg} \mathrm{ha}^{-1}$ and that of UFRGS $146155-3$ was $3643 \mathrm{~kg} \mathrm{ha}^{-1}$ or $115.2 \%$ better than the best check $(\mathrm{P}<0.01)$. It is important to emphasize that these yields have been obtained in plots that had not been sprayed with insecticide or fungicide.

For other important grain characteristics, the line UFRGS 146155-3 showed significant differences when compared with the check cultivars (Table 2). For test weight, thousand kernel weight UFRGS $146155-3$ (50.8 kg hL-1 and $34.8 \mathrm{~g}$ ) was superior than the check URS 21 (45.9 $\mathrm{kg} \mathrm{hL}^{-1}$ and $27.9 \mathrm{~g}$ ). UFRGS $146155-3$ was $10 \mathrm{~cm}$ shorter (plant height 100.8 $\mathrm{cm}$ ) than URS 21, and lodging was similar to that of URS 21 (Table 2).

Table 3. Days from emergence to flowering, days from flowering to maturation and days from emergence to maturation of the oat line UFRGS 146155-3 and the check cultivars evaluated in the Regional Trial of Oat Lines (ERLA 2016), National Trial of Oat Lines of first-year (EBLA 2017), and National Trial of Oat Lines of second-year (EBLA 2018)

\begin{tabular}{|c|c|c|c|c|c|c|}
\hline \multirow[b]{2}{*}{ Cultivars } & \multicolumn{5}{|c|}{ Days from emergency to flowering } & \multirow[b]{2}{*}{ \% URS 2} \\
\hline & 2016 & 2017 & 2018 & Mean & $\%$ best check each year & \\
\hline URS $21(T)$ & 84.3 & 76.5 & 78.6 & 79.8 & 104.9 & 100.0 \\
\hline UPFPS Farroupilha ( $\mathrm{T}$ ) & 85.8 & & & 85.8 & 101.9 & 101.9 \\
\hline URS Altiva (T) & & 70.0 & 74.7 & 72.3 & 100.0 & 93.3 \\
\hline Nr. of locations & 8 & 10 & 8 & 26 & 26 & 26 \\
\hline \multicolumn{7}{|c|}{ Days from flowering to maturation } \\
\hline URS $21(T)$ & 39.7 & 35.7 & 39.0 & 38.2 & 94.8 & 100.0 \\
\hline URS Corona (T) & 37.6 & 36.1 & 37.8 & 37.1 & 92.3 & 97.3 \\
\hline Nr. of locations & 7 & 8 & 6 & 21 & 21 & 21 \\
\hline \multicolumn{7}{|c|}{ Days from emergency to maturation } \\
\hline URS $21(T)$ & 125.0 & 112.9 & 116.9 & 118.3 & 101.4 & 100.0 \\
\hline URS Corona (T) & 125.0 & 113.7 & 115.3 & 118.0 & 101.2 & 99.8 \\
\hline UPFPS Farroupilha ( $T$ ) & 126.0 & & & 126.0 & 100.9 & 100.8 \\
\hline URS Altiva (T) & & 110.0 & 115.0 & 112.5 & 100.0 & 97.9 \\
\hline UFRGS $146155-3$ & 121.8 & 109.6 & 116.3 & $115.9 *$ & 99.4 & 98.0 \\
\hline Nr. of locations & 7 & 8 & 6 & 21 & 21 & 21 \\
\hline
\end{tabular}

** Mean significative different from that of URS 21 by the $t$ test of paired comparison $(P<0.01) ; *$ Mean significative different from that of URS 21 by the $t$ test of paired comparison $(P<0.05)$ 
For oat cultivar to be successful in the agronomic systems utilized by the farmers in the subtropical environments it needs to fit perfectly the windows between two summers crops. Earliness is an important trait for subtropical environments such as Southern Brazil, where oat plays an important role in grain production during the winter/spring seasons in no-tillage crop system rotations as a pre-soybean crop (Locatelli et al. 2007, Nava et al. 2016). The results of UFRGS 146155-3 for the traits related to the crop growth and total cycle are in Table 3. For the number of days from emergence to flowering, UFRGS $146155-3$ showed means of 78.5, 69.4, and 72.5 days respectively to 2016, 2017, and 2018, that was in average 6 days earlier than URS 21. The line UFRGS 146155-3 had mean number of days from flowering to maturation of 42.3, 39.1, and 44.0 days, not different from that of URS 21 (39.7, 35.7, and 39.0 days, respectively). For the number of days from emergence to maturation, significant differences $(P<0.05)$ were observed between UFRGS 146155-3 (115.9 days) and URS 21 (118.3 days) (Table 3). Line UFRGS 146155-3 was resistant to all strains of crown rust in 2015, and it had an infestation of very low severity in 2016; its resistance was overcome by strains of crown rust in 2017 and 2018 (Table 4). Despite the susceptibility to crown rust, the line showed very good test weight and thousand kernel weight (Table 2). The same outcome was seen with stem rust and UFRGS 146155-3, showing susceptibility to prevalent strains of stem rust. For black leaf spots caused by Pyrenophora chaetomioides Speg., UFRGS 146155-3 showed severity similar to those of the best checks (Table 4). Currently, the resistance to crown rust and stem rust has moderate importance, because all farms apply fungicide to oat crops when they harvested it for grain production.

The release of the line UFRGS 146155-3 as a cultivar with the name URS MONARCA represents a new option for the farmers in the sub-tropical environments of Brazil. It is a cultivar with high and stable grain yield, excellent grain quality,

Table 4. Crown rust severity, stem rust severity and leaf spot severity of the oat line UFRGS 146155-3 and the check cultivars evaluated in the Regional Trial of Oat Lines (2016), National Trial of Oat Lines of first year (2017), and National Trial of Oat Lines of second year (2018)

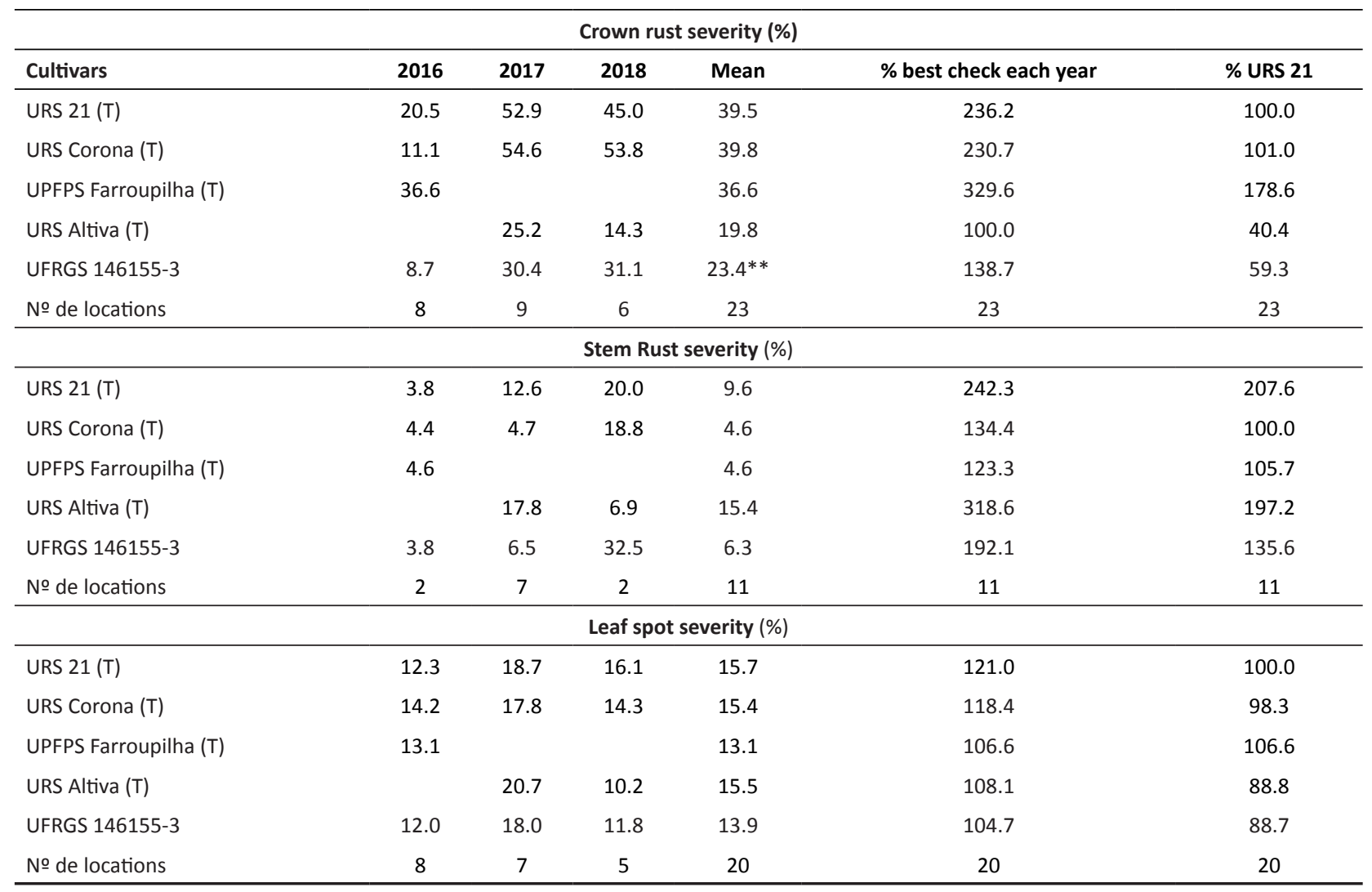

** Mean significative different from that of URS 21 by the T test of paired comparison; 
early with short plant height and good resistance to lodging. It also represents a new option for small industries that process oat grain; this is because UFRGS $146155-3$ has excellent grain quality, very good dehulling $(73,6 \%)$, low grain breakage (less of $1 \%)$, and excellent milling yield (>65\%).

\section{ACKNOWLEDGEMENTS}

This study was supported by the Rio Grande do Sul State Research Support Foundation (PRONEX/FAPERGS; grant number 16/0484-6)

To Comissão Brasileira de Pesquisa de Aveia (CBPA) for performing the experiments in different locations.

\section{REFERENCES}

Juliatti FC and Silva SA (2001) Antracnose: Colletotrichum gloesporioides Bertagnolli PF and Federizzi LC (1994) Cruzamentos artificiais em aveia. Pesquisa Agropecuária Brasileira 29: 601-606.

CONAB - Companhia Nacional de Abastecimento (2019) Follow-up of the Brazilian oat crop series of Brazil. Available at <https://www. conab.gov.br/info-agro/safras/serie-historica-das safras?start=10>. Accessed on March 18, 2019.

Locatelli AB, Federizzi LC, Milach SCK and McElroy AR (2007) Flowering time in oat: genotype characterization for photoperiod and vernalization response. Field Crops Research 106: 242-247.

Nava IC, Pacheco MT and Federizzi LC (2016) URS Altiva - a new oat cultivar with high agronomic performance. Crop Breeding and Applied Biotechnology 16: 254-260, 2016.

Rajhathy T and Thomas H (1974) Cytogenetics of oats. Genetics Society of Canada, Ottawa, 90p.

Reynolds M, Borrell A, Braun H, Edmeades G, Flavell R, Gwyn J, Jordan D, Pixley K and Rebetzke G (2019) Translational research for climate resilient, higher yielding crops. Crop Breed Genetics and Genomics 1: 190016.

Steel RGD and Torrie JH (1980) Principles and procedures of statistics a biometrical approach. McGraw-Hill Book Company, New York, 633p.

Zimmer CM, Ubert IP, Pacheco MT and Federizzi LC (2018) Molecular and comparative mapping for heading date and plant height in oats. Euphytica 214: 101. 